Brit. J. vener. Dis. (1957), 33, 198.

\title{
OBITUARY
}

\section{ANGUS ELRICK WILLIAM McLACHLAN}

Dr. A. E. W. McLachlan, Consultant in Venereology in the Bristol Clinical Area, and Lecturer on Venereal Diseases at the University of Bristol, died on August 15 in the Bristol Royal Infirmary, at the age of 58 years, after a brief illness.

Elrick McLachlan, a schoolmaster's son, joined the Black Watch direct from Heriot's School and within three months was a prisoner in Germany, where he spent the remainder of the first world war. He graduated in medicine at Edinburgh in 1924 and became one of that fortunate generation inducted into the craft of venereology by David Lees, under whom he served as Clinical Tutor in Venereal Diseases. In 1927 he obtained the Diploma in Public Health and later became a Fellow of the Royal Society, Edinburgh. For a time he was assistant to Hamilton Bailey in Birmingham, whence originated his collaboration in the indispensable "Pye's Surgical Handicraft". He went to London as Surgeon to Out-patients at St. Paul's Hospital and returned to venereology at the West London Hospital, Hammersmith. In 1938, he became director of the newly-built venereal diseases treatment centre at the Newcastle General Hospital. He rapidly made this a pre-eminent clinic for venereal diseases, with a world-wide reputation, and his departure to the kinder climate of Bristol in 1944 was regretted by all his colleagues.

He set and maintained high standards in his clinical work and expected his staff to conform. He had, however, the gift of suffering fools gladly, which made the confession of error almost a pleasure.
He kept in constant touch with new developments, and, once his native caution was satisfied, he was ever ready to introduce new methods of treatment in a rapidly changing field of medicine. With Hilda Johns he pioneered the Tyneside survey into the social aspects of venereal disease and during the same period he wrote his "Handbook of Diagnosis and Treatment of Venereal Diseases," as well as numerous contributions to local and national journals.

Teaching he took very seriously, and his lectures to students, liberally illustrated with his own lantern slides, underwent constant revision; with postgraduate students his methods were no less effective if a little more brusque-he threw them in at the deep end but was always there to keep their heads above water. A knowledge of German acquired while a prisoner of war and a colloquial familiarity with French learnt on many visits to that country gave him a detailed knowledge of the continental literature of his subject which often surprised visitors. He had been a keen supporter of the Medical Society for the Study of Venereal Diseases, of which he was a Vice-President, and served on the Editorial Committee of the British Journal of Venereal Diseases. His private interests were good talk, antique furniture, Persian rugs, and old venereological texts and incunabula, of which he had an enviable collection.

He leaves a widow, Helen, whom many of his colleagues will remember as a delightful hostess, and to whom our sympathy is extended.

C.P.H

\section{CHARLES R. REIN}

The many friends and acquaintances in England of Charles R. Rein were shocked to learn of his sudden death at the early age of 52. After a successful undergraduate career, he was awarded the M.D. of the University of Michigan in 1928. At the time of his death he was Clinical Professor of Dermatology at the New York Undergraduate School of Medicine, Medical Consultant of the World Health Organization, and a member of many professional societies.

Rein's work and writings are so well known and admired that they do not need recapitulation in detail. However, special mention should be made 
of the Rein-Bossak Test, his successful campaign against yaws in Haiti, and his stimulating contributions to the many international conferences that he attended.

He was a prodigious traveller, mainly in the cause of furthering venereology, and his guidance and help were much appreciated in many countries besides the Americas, ranging from Finland to Israel. His infectious enthusiasm, even in difficult climatic conditions, in Bangkok during the W.H.O. International Yaws Symposium in 1952, is well remembered. In addition to the official programme, he was interested in everything and everyone around him and he was an indefatigable sightseer and photographer.

His generous nature was perhaps best exemplified by the help he rendered to visitors to his laboratory where everything was put at their disposal and, if necessary, contacts were made to expedite their business and pleasure whilst in America. His life was characterized by a zest for hard work, the joy of living, and love for his family, to whom we offer, in their irreparable loss, this appreciation.
I.N.O.P.

\section{BOOK REVIEW}

Biology of the Treponematoses. By Thomas Bourne Turner and David H. Hollander. 1957. Pp. 272, 21 illus. World Health Organization. Monograph Series No. 35. (30s.; \$6; 18 Swiss Frs.)

The discovery, in 1905, of Treponema pallidum by Schaudinn and Hoffman (1905 a, b, c) was followed by an intense amount of investigation of the morphology and biology of this organism on a world-wide scale by many workers. In due course excellent summaries of these researches were written by various authors including $\mathrm{W}$. Bulloch of Great Britain. After the initial work, the impetus of these investigations seemed to slow down. This may have been accentuated by the practical necessity of improving the serological diagnostic techniques which were then in vogue, as well as the inability of workers to propagate this organism by means of artificial media. This relatively short phase was soon followed by a resurgence of activity, and investigations were renewed into the habits and the relationships of the various treponemes, and the diseases for which, by then, they were known to be responsible. In the van of these workers was the Baltimore group headed by T. B. Turner, the senior co-author of this monograph. In 1950, this work was further stimulated by the establishment, at the Johns Hopkins School of Hygiene and Public Health, of the World Health Organization International Treponematosis Laboratory Center. Thus, Turner and his associates have had an unique experience of the laboratory problems of treponemal infections extending over many years.
In essence this monograph is an account of the researches carried out at this laboratory over the years. The authors modestly comment that their work adds to, and does not supersede, the knowledge already on record at the beginning of their investigations.

The results obtained are examined and the implications, together with some reasonable speculation, are propounded. The researches recorded include work performed concerning experimental treponemal diseases in laboratory animals, the characteristics of treponemes in vitro, immunity phènomena including appreciations of the treponemal immobilization test and treponemal agglutination tests, the antigenic relationships between various treponemal strains, and the response of treponemes to drugs, such as the antibiotics. The final chapter consists of an interesting and critical discussion of the data obtained.

This monograph is an authoritative, well written, easily read, and stimulating dissertation. It should be of the greatest interest to all those, clinicians and serologists alike, who are interested in the treponemal diseases.

I.N.O.P.

\section{REFERENCES}

Bulloch, W. (1931). In Medical Research Council: "A System of Bacteriology", vol. 8, chap. 7, p. 185. H.M.S.O., London. Schaudinn, F., and Hoffmann, E. (1905). Dtsch. med. Wschr., 31, 711 (1905). Berl. klin. Wschr., 42, 673.

(1905). Arb. GesundhAmte (Berl.), 22, 527. 